KULTURA I WARTOŚCI

ISSN 2299-7806

NR 13/ 2015

ARTYKULY, s. 73-93

\title{
HUSSERLA UJECIE KRYZYSU A FENOMENOLOGIA TRANSCENDENTALNA
}

\author{
Agnieszka Wesolowska
}

\begin{abstract}
Fenomenologia jako nauka dotycząca transcendentalnej subiektywności została ugruntowana w związku z krytycznym namysłem nad ideą poznania. W niniejszym artykule rozważania na temat kryzysu zostają przedstawione w rezultacie analiz dotyczących teoretycznego i praktyczno-etycznego motywu myśli Husserla. Z takiego punktu widzenia fenomenologia może być rozumiana jako wiedza umożliwiająca jedność poznania i odsłaniająca rozstrzygnięcia istotne dla życia. W artykule zostaje pokazane, że idea fenomenologii ewoluuje $\mathrm{w}$ związku z rozważaniami obejmującymi horyzont klasycznych problemów filozoficznych: epistemologicznych, metafizycznych oraz etycznych.
\end{abstract}

Słowa kluczowe: fenomenologia, kryzys nauk, transcendentalna redukcja, poznanie

Głównym celem realizowanym $\mathrm{w}$ ramach podejmowanych rozważań, jest udowodnienie tezy, że idea fenomenologii transcendentalnej powstaje $\mathrm{w}$ związku z rozważaniami dotyczącymi kryzysu. Projekt fenomenologii transcendentalnej wiąże się z namysłem Husserla nad ogólnym kryzysem człowieczeństwa, kryzysem nauk historycznych oraz przyrodniczych będącym częścią ogólnego kryzysu kultury. W niniejszym artykule rozważania dotyczące kryzysu zostaną przedstawione w dwóch etapach. W pierwszym ukażemy, że idea fenomenologii transcendentalnej powstaje $\mathrm{w}$ związku z rozważaniami dotyczącymi ogólnego kryzysu przejawiającego się w sferze nauki i człowieczeństwa, w sferze teorii i praktyki. W drugiej części tekstu rozważymy możliwość prze-

AGNIESZKA WESOŁOWSKA, doktor, Instytut Filozofii Uniwersytetu Śląskiego, Zakład Antropologii Filozoficznej i Filozofii Cywilizacyjnej, Katowice, Polska; adres do korespondencji: ul. Bankowa 11, 40-007 Katowice. E-mail: aletheia2@interia.pl 
zwyciężenia kryzysu, wychodząc od koncepcji fenomenologicznej redukcji.

\section{Fenomenologia a problem kryzysu}

W Badaniach logicznych (1900-1901), stanowiących „punkt zwrotny” rozważań Husserla w drodze do fenomenologii, autor, dążąc do ukazania nowych podstaw czystej logiki i epistemologii, stawia pytania dotyczące warunków możliwości wiedzy. W odniesieniu do rozważań Husserla zawartych już w Prolegomenach do czystej logiki (w tym w charakterystycznej dlań krytyce psychologizmu), można dostrzec, że próba przedstawienia warunków możliwego poznania biegnie dwoma torami. Ten aspekt rozważań Husserla uwyraźnia Dan Zahavi: „po pierwsze, jest on zaangażowany $\mathrm{w}$ krytyczny projekt, który zmierza do pokazania, że popularne w tym czasie stanowisko nie było w stanie faktycznie wyjaśnić możliwości wiedzy. Po drugie, próbuje on w bardziej pozytywnym kroku przedstawić kilka warunków, jakie muszą być spełnione, jeśli poznanie ma być możliwe"1. Warto zaakcentować, że o ile centralnemu zadaniu Prolegomenów, kulminującemu się w analizie warunków możliwości wiedzy, towarzyszy cel par excellence teoretyczny, o tyle w dążeniu do ukazania zdolności, jakie dowolny podmiot musi posiadać, jeśli ma być władny osiągnąć poznanie, w dążeniu wymagającym otwarcia na podmiotowość, świadomość i jej dokonania, życie ,ja” w nastawieniu naturalnym, przejawia się motywacja praktyczna. Współwystępowanie obu tendencji (motywacji), dostrzegalne już na wczesnym etapie Husserlowskiego filozofowania, ma dla niniejszych rozważań niezwykle istotne znaczenie. Okazuje się ono dla rozwoju fenomenologii (od fenomenologii jako nauki do jej postaci transcendentalnej) rozstrzygające. Wspólistnienie to, przejawiające się już w Badaniach logicznych - a podjęte w Filozofii jako ścistej nauce, Ideach fenomenologii oraz Ideach czystej fenomenologii i fenomenologicznej filozofii - kulminuje się właśnie w ostatniej pracy Husserla, zatytułowanej Kryzys nauk europejskich i fenomenologia transcendental$n a$, i okazuje się trwałym rysem jego filozofowania. Odpowiedź na fundamentalne pytania teorii nauki pozostaje w korelacji z motywacją praktyczną (etyczną), uwyraźniającą się szczególnie mocno w rozważaniach dotyczących kryzysu. Husserl pokazuje świadomość jako centralną i sprawczą dziedzinę bytu, podlegającą odrębnym zasadom, dziedzinę,

${ }^{1}$ D. Zahavi, Fenomenologia Husserla, tłum. M. Święch, Wydawnictwo WAM, Kraków 2012, s. 14. 
w której funkcjonowaniu i dokonaniach istotne znaczenie odgrywają racje praktyczne, etyczne i aksjologiczne. Podmiotem sprawczym ,zarówno poznania, jak i naturalnego nastawienia, pozostaje zawsze „ja”, „któremu - pisze Robert Sokolowski - dany jest świat wraz ze swoimi rzeczami, który będąc częścią tego świata, jednocześnie znajduje się w jego intencjonalnym posiadaniu" 2 . Husserl pokazuje, że zajęcie stanowiska fenomenologicznego umożliwia przyglądanie się światu $\mathrm{w}$ taki sposób, w jaki jest on intencjonalnie ujmowany jeszcze w nastawieniu naturalnym. Odwołajmy się w tym kontekście do sformułowań U11richa Melle'go, który ujmuje fenomenologię jako „wszechogarniającą filozofię transcendentalną i absolutną naukę o bycie", w której wszystko, co przedmiotowe, jest rozpatrywane jako pozostające w możliwej korelacji ze świadomością ${ }^{3}$. Zdaniem tego komentatora „dotyczy to także specyficznych fenomenologicznych przedmiotów, zjawisk, sądów (opinii) i znaczeń, które zostają odniesione do konstytuującej, absolutnej świadomości transcendentalnej"4.

W perspektywie obranego przez nas punktu widzenia, Husserlowską refleksję transcendentalną można ujmować $\mathrm{w}$ aspekcie współistnienia teoretycznego namysłu nad warunkami poznania z motywacją praktyczną (w tym przede wszystkim etyczną i aksjologiczną), kulminującą się zwłaszcza - jak już zaznaczyliśmy - w rozważaniach dotyczących ogólnego kryzysu. Husserl ukazuje fenomenologię jako naukę o źródle poznania i wykazuje konieczność zajęcia stanowiska transcendentalnego, w którego świetle ujawniają się dokonania transcendentalnej subiektywności. Zajęcie stanowiska transcendentalnego umożliwia - na co zwraca uwagę Piotr Łaciak - uświadomienie sobie sprawczej funkcji świadomości, w której tworzy się wszelka obiektywność oraz „rozpo-

${ }^{2}$ R. Sokolowski, Wprowadzenie do fenomenologii, thum. M. Rogalski, Wydawnictwo WAM, Kraków 2012, s. 59.

3 „Die Phänomenologie schließlich gilt Husserl als die »allumfassende Transzendentalphilosophie" und »absolute Seinswissenschaft", »in der alles Gegenständliche in seine Korrelationen aufgelöst wird «”. U. Melle, Einleitung des Herausgebers, [w:] E. Husserl, Vorlesungen über ethik und wertlehre 1908-1914, hrsg. von U. Melle, [w:] Husserliana Edmund Husserl, Gesammelte Werke, bd. 28, Kluwer Academic Publishers, Dordrecht-Boston-London 1950, s. XL. Brak adnotacji o autorze thumaczenia oznacza, iż autorka niniejszego artykułu opiera się na tłumaczeniu własnym.

4 „Das gilt selbst für die "spezifisch phänomenologischen Gegenstände«, die Erscheinungen, Meinungen und Bedeutungen, die durch Rückgang auf das letztkonstituierende absolute Bewußtsein transzendental aufgeklärt werden”. Tamże. 
znanie jej konstytuujących dokonań jako funkcji, od których zależy ważność naszego ujęcia naturalnego świata" 5 .

W rezultacie namysłu nad ideałem naukowej jedności (jedności nauk) oraz filozofii jako nauki, filozofii pierwszej, ostatecznie uzasadnionej, prawdziwej i autentycznej, Husserl wyjaśnia, w jaki sposób jest możliwe samozrozumienie poznania i konstytuująco-transcendentalnego życia świadomości (funkcji świadomości). W kontekście doniosłości problemu możliwości filozofii jako nauki Husserl pisze wprost: „Nie ma w całych nowożytnych czasach potężniejszej idei niż idea nauki. Pomyślana w idealnie doprowadzonej do końca postaci była ona samym rozumem [...]. Do dziedziny ścisłej nauki należą [...] z pewnością także wszystkie ideały teoretyczne, aksjologiczne i praktyczne, które naturalizm, poddając je empirystycznej interpretacji, zarazem zafałszowuje"6. Swój filozoficzny projekt Husserl rozwija wówczas, gdy w odniesieniu do idei jedności nauki, filozofia uległa rozproszeniu oraz podziałowi na różne szkoły i kierunki, tracąc ,jedność duchowej przestrzeni" możliwą do urzeczywistnienia we wspólnym celu, przedmiocie oraz metodzie. „Duchowa nędza naszych czasów - pisze Husserl w Filozofii jako ścistej nauce stała się faktycznie nie do zniesienia. [...] Wszelkie życie jest zajmowaniem postaw, wszelkie zajmowanie postaw dokonuje się $\mathrm{w}$ zasięgu jakiejś powinności, jakiejś instancji, która wyrokuje o prawomocności lub nieprawomocności, zgodnie z normami pretendującymi do absolutnej mocy obowiązującej. [...] Naturaliści i historyści walczą o światopogląd, a jednak jedni i drudzy $z$ różnych stron pracują nad tym, by idee przeinterpretować na fakty, a wszelką rzeczywistość, wszelkie życie przekształcić w niezrozumiałą mieszaninę faktów, wolną od jakichkolwiek idei. Zabobon faktu wszystkim im jest wspólny"7. Zamiast filozofii dążącej do uzasadnienia poznania, filozofia występująca w postaci światopoglądowej, naturalistycznej, irracjonalnej, a nawet historyzmu „nie jest jeszcze - pisze Józef Czarkowski - w ogóle nauką, wszystko bez wyjątku jest w niej sporne i stanowi sprawę indywidualnych przekonań i punktów widzenia" ${ }^{8}$. Konsekwencją upadku ideału filozofii jako nauki i rozpadu naukowej jedności staje się, z jednej strony, niejasność i zachwianie sensu badanego przez nauki przedmiotu, a $\mathrm{z}$ drugiej - zafałszowanie norm i przekształcenie życia $\mathrm{w}$ irracjonalną mieszaninę faktów. W rozumieniu

${ }^{5}$ P. Łaciak, Anonimowość jako granica poznania w fenomenologii Edmunda Husserla, Wydawnictwo Uniwersytetu Śląskiego, Katowice 2012, s. 28.

${ }^{6}$ E. Husserl, Filozofia jako ścista nauka, tłum. W. Galewicz, Fundacja "Aletheia", Warszawa 1992, s. 17.

${ }^{7}$ Tamże, s. 73.

${ }^{8}$ J. Czarkowski, Filozofia czystej świadomości, Wydawnictwo UMK, Toruń 1994, s. 6. 
Husserla tymczasem „od swoich pierwszych początków filozofia pretendowała do tego, aby być ścisłą (strenge) nauką, i to nauką, która czyniłaby zadość najwyższym potrzebom teoretycznym, a pod względem etycznoreligijnym umożliwiałaby życie regulowane przez czysto racjonalne normy" . Husserla projekt fenomenologii transcendentalnej okazuje się projektem filozofii jako ścisłej i autentycznej nauki, dążącej do sprostania celom zarówno teoretycznym, jak i motywacjom (potrzebom) praktycznym. Warto odwołać się w tym kontekście do wypowiedzi Józefa Czarkowskiego, który stwierdza, że „doniosłość problemu możliwości zbudowania autentycznej wynika stąd, że problem ten ma wymiar nie tylko teoretyczny, ale i praktyczny. Filozofia jest, zdaniem Husserla, absolutnie niezbędna do wyjaśnienia rzeczywistości i rozumnego ukształtowania życia. Bezład i deformacje w filozofii pociągają za sobą kryzys kultury i całego życia ludzkiego. Nauki szczegółowe nie są w stanie zastąpić filozofii i wyjaśnić nam sensu życia i świata" ${ }^{10}$. Zdaniem Husserla, „tylko nauka może ostatecznie przezwyciężyć nędzę, która pochodzi z nauki. [...] Jeżeli pewne specjalne, ale $\mathrm{w}$ wielkiej klasie nauk wymagane nastawienie metodyczne, [...] przeradza się $\mathrm{w}$ niezdolność do przejścia $\mathrm{w}$ inne nastawienia [...] - to na wszystkie te i tym podobne bolączki istnieje tylko jedno lekarstwo: naukowa krytyka, radykalna [...] nauka filozoficzna, której tu bronimy. Światopoglądy mogą się spierać, tylko nauka może rozstrzygać; a rozstrzygnięcie, którego dokona, zamknięte jest na pieczęć wieczności”"11.

W takim świetle, kryzys nauki w rozumieniu Husserla nie znaczy nic innego, jak tylko to, że problematyczna stała się jej autentyczna istota, jej sposób stawiania zadań i wypracowywania odpowiedniej dlań metody. Kryzys, o którym pisze Husserl, wiąże się z obiektywno-naukową tematyzacją świata i polega na tym, że nauki zatraciły związek z tym, co stanowi podstawę ich sensu, ulegając zaślepieniu ideą tego, co obiektywne, ideą świata jako bytu w sobie, wolnego od wszelkiej relatywności i subiektywności. Kryzys, który ukazuje twórca fenomenologii, jest w istocie kryzysem nauki, kryzysem racjonalizmu, który uległ ułudzie obiektywizmu i naturalizmu. W rezultacie namysłu nad tendencją obiektywistyczną Husserl wykazuje, że kryzys nauki, kultury i człowieczeństwa ma swe źródło w zapoznaniu tego, co źródłowe. W odniesieniu do kondycji nauk, kultury i człowieczeństwa Husserl wykazuje konieczność zajęcia stanowiska transcendentalnego, w którego świetle ujawniają się dokona-

\footnotetext{
${ }^{9}$ E. Husserl, Filozofia jako ścisła nauka, dz. cyt., s. 7.

${ }^{10}$ J. Czarkowski, Filozofia czystej świadomości, dz. cyt., s. 6.

${ }^{11}$ E. Husserl, Filozofia jako ścista nauka, dz. cyt., s. 74.
} 
nia transcendentalnej subiektywności. Przeprowadzając krytykę nauk pozytywnych, pokazuje że w celu przywrócenia nauce i filozofii ich roli należy powrócić do - pomijanej jako wyjściowy punkt badań - sfery przeżyć, sfery doświadczenia źródłowego, czyli do podstawy, którą stanowi konstytuująca subiektywność. W rezultacie idealizacji, odejścia od życia, nauki matematyczno-przyrodnicze oddaliły się od tego, co źródłowe.

Husserla rozważania zawarte w Kryzys nauk europejskich mają charakter przełomowy i uniwersalny. Pytanie wstępne, inaugurujące fenomenologiczne rozważania dotyczące relacji między filozofią, kulturą i nauką, jest pytaniem o to, co doprowadziło do tego, że dumna ze swych praktycznych i teoretycznych sukcesów nowożytność popadła w rosnące niezadowolenie z siebie. Mamy przy tym na uwadze poglądy, które doprowadziły do kryzysu nauk, i które sam Husserl zawsze zwalczał, w szczególności w swej krytyce naturalizmu, historyzmu i filozofii światopoglądowej. W takim sensie należy również rozumieć ten fragment Kryzysu, w którym autor wyraża przekonanie, że potężny prąd religijnej niewiary oraz filozofii wyrzekającej się naukowości zalewa europejskie człowieczeństwo $^{12}$. Zdaniem Janssena, takie rozumienie wspomnianego zdania mówiącego o rozbracie filozofii i nauki wynika $\mathrm{z}$ kontekstu, $\mathrm{w}$ jakim ono zostało umieszczone ${ }^{13}$. Sama refleksja o naukowości, której częścią jest to zdanie, została zatytułowana Zaprzeczenie możliwości filozofii naukowej $^{14}$ Zastana sytuacja wyjściowa, jaką jest rozdzielenie filozofii i nauki, sytuacja, którą opisuje zdanie „filozofia jako nauka, jako poważna, ścisła, co więcej, apodyktycznie ścisła nauka - ten sen jest skończony"15, wiąże się z namysłem Husserla nad filozofią, namysłem, który jest konieczny do potwierdzenia tego, że filozofia jako nauka jest możliwa. W Kryzysie nauk europejskich Husserl pozostaje wierny dewizie sformułowanej w Filozofii jako ścistej nauce, a głoszącej, że duchowa nędza naszych czasów może być ostatecznie przezwyciężona przez naukę:

\footnotetext{
${ }^{12}$ Tenże, Die Krisis der europäischen Wissenschaften und die transzendentale Phänomenologie. Eine Einleitung in die phänomenologische Philosophie, hrsg. von W. Biemel, [w:] Husserliana - Edmund Husserl, Gesammelte Werke, bd. 6, Kluwer Academic Publishers, Den Haag 1962, s. 508.

${ }^{13}$ P. Janssen, Geschichte und Lebenswelt. Ein Beitrag zur Diskussion von Husserls Spätwerk, Martinus Nijhoff, Den Haag 1970, s. 142.

${ }^{14}$ E. Husserl, Die Krisis der europäischen Wissenschaften, dz. cyt., s. 508. Cyt. za polskim przekładem fragmentów Kryzysu... - tenże, Kryzys europejskiego człowieczeństwa a filozofia, tłum. J. Sidorek, Fundacja Aletheia, Warszawa 1993, s. 99.

${ }^{15}$ E. Husserl, Die Krisis der europäischen Wissenschaften, dz. cyt., s. 508. „Philosophie als Wissenschaft, als ernstliche, strenge, ja apodiktisch strenge Wissenschaft - der Traum ist ausgeträumt".
} 
„[...] istnieje tylko jedno lekarstwo - czytamy w Filozofii jako ścistej nauce - naukowa krytyka, a do tego radykalna, zaczynająca budowę od dołu, oparta na pewnych fundamentach i postępująca naprzód wedle najściślejszych metod nauka: nauka filozoficzna, której tu bronimy" ${ }^{\prime 16}$. Rozwój projektu fenomenologii dokonuje się w związku z dążeniem Husserla do urzeczywistnienia filozofii jako nauki ścisłej, nauki o źródle wszelkiego poznania. O ile wszystkie pozytywne nauki - pisze Husserl - są naukami pozostającymi w transcendentalnej naiwności, nieprzekraczającymi nastawienia naturalistycznego i ostatecznie zastanymi w swych przesądach, o tyle fenomenologia, umożliwiająca odsłonięcie transcendentalnej podstawy zakrytej w postawie naturalnej, okazuje się nauką prowadzącą do przezwyciężenia kryzysu. Zamiast niedorzecznej obiektywistycznonaturalistycznej interpretacji świata i człowieka, fenomenologia jako nauka uwalnia od przesądów i ukazuje subiektywność konstytuującą świat - i jako taka okazuje się nauką wolną od jakichkolwiek obiektywistycznych interpretacji.

\section{Możliwość przezwyciężenia kryzysu. Koncepcja redukcji fenomenologicznej}

Możliwość przezwyciężenia kryzysu wiąże się z koncepcją fenomenologicznej redukcji. Redukcja, literalnie rzecz biorąc, polega na zawieszeniu, wzięciu w nawias generalnej tezy naturalnego nastawienia, owego uniwersalnego, nietematycznie przeżywanego przesądu naturalnego doświadczenia, bezwiednie przenikającego do nauki i filozofii. O ile świat naturalny istnieje w ruchu stałej względności obowiązywania, o tyle sferą pierwotną, źródłem wszystkich dziedzin bytowych, a zarazem residuum fenomenologicznej redukcji jest świadomość transcendentalna. „Konsekwentna realizacja redukcji fenomenologicznej - pisze Husserl - pozostawia nam więc po stronie noetycznej otwartą nieskończoną dziedzinę czystego życia świadomości, a po stronie jego noematycznego korelatu domniemany świat jako taki. W ten oto sposób fenomenologicznie medytujące Ja może stać się nieuprzedzonym obserwatorem siebie samego nie tylko co do szczegółów, ale również co do całokształtu, które dla niego istnieja i tak, jak dla niego istnieją. [...] Dopiero to nowe nastawienie pozwala mi zobaczyć, że wszechświat, a w ten sposób również wszelki w ogóle naturalnie doświadczany byt, istnieje tylko dla mnie, istnieje z całym swoim aktualnie posiadanym sensem jako wyłącznie ze względu na mnie obowiązujący byt, jako cogitatum moich zmieniających się i w tej

\footnotetext{
${ }^{16}$ Tenże, Filozofia jako ścista nauka, dz. cyt., s. 74.
} 
zmianie wzajemnie powiązanych cogitationes; i tylko $\mathrm{w}$ takiej postaci utrzymuję go w mocy obowiązywania"17. Podczas gdy właściwe nauce myślenie obiektywistyczne jest nakierowane na świat jako byt w sobie, oczyszczony $z$ tego, co relatywne i subiektywne, to celem filozofii fenomenologicznej jest pokazanie, że takie zabsolutyzowanie świata ma źródło w niedorzecznej interpretacji, właściwej obiektywistycznej filozofii, a sam świat czerpie swój sens z subiektywności transcendentalnej ${ }^{18}$.

Koncepcja redukcji rzuca nowe światło na kwestię podmiotowości. Można sformułować tezę, że w wyniku uchylenia świata centralny problem filozofii Husserla przybiera postać pytania: jak jest możliwe, że „ja”, będące jako podmiot faktycznym indywiduum w świecie. może być zarazem subiektywnością konstytuującą świat. Problem ten, sprowadzający się do tego, że „ja” jest zarazem „podmiotem dla świata” oraz „obiektem w świecie”, Husserl określa jako „paradoks ludzkiej podmiotowości" ${ }^{19}$. Jak zauważa James Mensch, paradoks ten kryje w sobie trudność związaną z pogodzeniem tego, że „podmiot, będący częścią świata, konstytuuje cały świat i traktuje przy tym siebie jako część tej całości”"20. W odniesieniu do omawianego problemu warto przytoczyć słowa Lyotarda, który trafnie dostrzega, że redukcja „pozwala nam właśnie uchwycić, jak istnieje dla nas byt w sobie, to znaczy w jaki sposób transcendencja przedmiotu może $\mathrm{w}$ immanencji podmiotu mieć sens transcendencji. Redukcja przywraca podmiotowi jego prawdę czynnika konstytuującego rozmaite formy transcendencji, prawdę tkwiącą implicite w jego wyobcowanej postaci, jaką jest postawa naturalna"21.

Epoché zapewnia możliwość obserwacji indywidualnego, subiektywnego bieguna przeżyć, przy czym jest to obserwacja bezstronna, pozostawiająca świat oraz wszelkie przyjęte dotąd przeświadczenia w transcendentalnym wyłączeniu. W nastawieniu fenomenologicznym bowiem - „ponad Ja pochłoniętym światem osadza się (etabliert) Ja fenomenologiczne jako nieuprzedzony obserwator (uninteressierter Zuschauer)"22. Konse-

${ }^{17}$ Tenże, Medytacje kartezjańskie $z$ dodaniem uwag krytycznych Romana Ingardena, tłum. A. Wajs, PWN, Warszawa 1982, s. 53-54.

${ }_{18}$ Zob. P. Janssen, Geschichte und Lebenswelt, dz. cyt., s. 31-41.

${ }^{19}$ Zob. E. Husserl, Die Krisis der europäischen Wissenschaften, dz. cyt., s. 182. Paragraf 53. Kryzysu... Husserl opatruje tytułem: „Die Paradoxie der menschlichen Subjektivität: das Subjektsein für die Welt und zugleich Objektsein in der Welt".

${ }^{20}$ J. Mensch, Manifestation and the Paradox of Subjectivity, „Husserl Studies” 2005, vol. 21, s. 35.

${ }_{21}$ J.-F. Lyotard, Fenomenologia, tłum. J. Migasiński, Wydawnictwo KR, Warszawa 2002, s. 42.

${ }^{22}$ E. Husserl, Medytacje kartezjańskie, dz. cyt., s. 50. 
kwentnie przeprowadzona epoché, rozumiana jako sposób oczyszczenia z naturalnych domniemań, umożliwia przyglądanie się własnym przeżyciom $\mathrm{z}$ perspektywy nieuprzedzonego, niezaangażowanego obserwatora. Epoché jest w rozumieniu Husserla aktem oczyszczenia spojrzenia z tego, co relatywno-naturalne, możliwością wyzwolenia podmiotu z ograniczeń sensu oraz $\mathrm{z}$ relatywizmu będącego konsekwencją uprzednio zajmowanej postawy światowej.

Transcendentalna epoché, w której ramach dokonuje się zmiana postawy „ja”, nie implikuje podwojenia ani ,ja”, ani świata. Redukcja nie służy również w żaden sposób separacji świadomości od świata. Redukcja, obejmująca transcendentalnym nawiasem twierdzenie o istnieniu świata, prowadzi do odkrycia źródłowej tezy, to znaczy stwierdzenia ego cogito. Bezstronna tematyzacja naszego konstytuującego życia pozwala stwierdzić, że tym, co w nastawieniu naturalnym jest spełniane nietematycznie, okazuje się teza ,ja jestem”. Sam Husserl w Erste Philosophie uznaje teze ,ja jestem" za punkt wyjścia wszelkiej prawdziwej filozofii, tezę, od której rozpoczyna się filozofowanie ${ }^{23}$. Redukcja umożliwia, zdaniem Husserla, ,systematyczne przebadanie ego ze względu na to, co należy do niego $\mathrm{w}$ aktach i zdolnościach i co realizuje się $\mathrm{w}$ nich jako intencjonalne dokonanie" 24 . Niezaangażowany obserwator, oglądający siebie w trakcie swych dokonań, jest zarazem podmiotem rozumnie wartościującym oraz mogącym przyglądać się konstytutywnym rezultatom swej świadomości. W Ideach II twórca fenomenologii artykułuje explicite istotne znaczenie redukcji fenomenologicznej następująco: „[...] tym, co wyzwalające $\mathrm{w}$ tej niewątpliwie prawomocnej (gültig) fundamentalnej metodzie najbardziej pierwotnego określania sensu, jest to, że wyswobadza nas ona od ograniczeń sensu [płynących z] naturalnego nastawienia, jako też każdego nastawienia relatywnego. Człowiek zajmujący postawę naturalną (der natürliche Mensch), w szczególności badacz-przyrodnik, nie zauważa tych ograniczeń, nie zauważa, że wszystkie jego wyniki są zao-

\footnotetext{
${ }^{23}$ Tenże, Erste Philosophie (1923/24), teil 2: Theorie der phänomenologischen Reduktion, hrsg. von R. Boehm, [w:] Husserliana - Edmund Husserl, Gesammelte Werke, bd. 8, M. Nijhoff, Den Haag 1959, s. 42. „Indessen so einleuchtend diese in der Tat sehr natürliche Überlegung erscheinen mag und so sehr das »Ich bin« sich als eine zufällige und gar nicht bevorzugte Besonderung der erfahrenen Weltexistenz darbietet, man kann doch die Ansicht vertreten, und vielleicht mit sehr viel besseren Gründen, daß vielmehr der Satz »Ich bin« das wahre Prinzip aller Prinzipien und der erste Satz aller wahren Philosophie sein muß".

${ }^{24}$ Tenże, Die Krisis der europäischen Wissenschaften, dz. cyt., s. 84. Cyt. za polskim przekładem Kryzysu... - Tenże, Kryzys nauk europejskich i fenomenologia transcendentalna, tłum. S. Walczewska, Wydawnictwo Rolewski, Toruń 1999, s. 89.
} 
patrzone pewnym wskaźnikiem, który jest oznaką ich relatywnego jedynie sensu. Nie zauważa, że naturalne nastawienie nie jest jedynym możliwym, że dopuszcza skierowanie spojrzenia, dzięki którym uwydatnia się absolutna konstytuująca przyrodę świadomość, w stosunku do której wszelka przyroda musi być relatywna na mocy $\mathrm{z}$ istoty płynącej odpowiedzialności (Wesenskorreelation) pomiędzy tym, co konstytuujące, a tym, co konstytuowane" ${ }^{25}$. Uchylenie przeświadczenia o istnieniu świata, dokonane w ramach redukcji, powoduje modyfikację doświadczenia spełnianego w sposób nie uświadamiany przez podmiot w nastawieniu naturalnym. „Zmodyfikowane w ten sposób, transcendentalne doświadczenie - pisze w Medytacjach kartezjańskich Husserl - polega tedy na tym, że [pozostając w jego obrębie] przypatrujemy się danemu transcendentalnie zredukowanemu cogito i opisujemy je, nie dokonując przy tym jednak, jako spełniające akt refleksji podmioty, naturalnego uznania $\mathrm{w}$ bycie (Seinssetzung), które zawarte jest $\mathrm{w}$ realizującym się pierwotnie wprost spostrzeżeniu lub innym cogito, uznania w bycie, którego zanurzające się wprost $\mathrm{w}$ ten świat Ja rzeczywiście [przedtem] dokonało. Tym samym jednak, na miejscu przeżycia wyjściowego pojawia się przeżycie istotowo odmienne; o tyle wolno nam więc powiedzieć, że refleksja zmienia pierwotnie przeżycie. [...] Właśnie na tej drodze możliwa staje się ta wszelka, przede wszystkim opisowa, wiedza doświadczeniowa (Erfahrungswissen), której zawdzięczamy wszelką dającą się pomyśleć znajomość i poznanie naszego życia intencjonalnego. To samo powiedzieć można również o refleksji transcendentalno-fenomenologicznej”" Dzięki redukcji staje się możliwe, po pierwsze, odsłonięcie samego fenomenologicznego residuum, to znaczy transcendentalnej świadomości nieskażonej światowymi apercepcjami, a po drugie - tematyzacja konstytuującego życia naszej świadomości.

Okazuje się, że przejście od nastawienia naturalnego do nastawienia transcendentalnego nie dotyczy świata (niczego w nim nie zmienia), lecz jest przemianą samego ,ja”. „Jeśli Ja oddające się światu - pisze autor Medytacji kartezjańskich - w naturalny sposób całym swoim doświadczeniem i pogrążające się $\mathrm{w}$ nim innymi jeszcze aktami swego życia określimy jako Ja zainteresowane światem, to fenomenologicznie zmodyfikowane i utrzymywane nieustannie $\mathrm{w}$ tym charakterze nastawienie polega na tym, że prowadzi ono do zaistnienia pewnego rozwarstwienia $\mathrm{w}$ ob-

\footnotetext{
25 Tenże, Idee czystej fenomenologii i fenomenologicznej filozofii, ks. 2, thum. D. Gierulanka, PWN, Warszawa 1974, s. 254-255.

${ }^{26}$ E. Husserl, Medytacje kartezjańskie, dz. cyt., s. 48-49.
} 
rębie Ja (Ichspaltung) [...]"27. Można w tym kontekście zaryzykować tezę, że wraz ze zmianą nastawienia, oczyszczenia spojrzenia $z$ wszelkich domniemań dotyczących tego, co jest, dokonuje się szczególnego rodzaju przemiana ,ja", ponieważ w nastawieniu transcendentalnofenomenologicznym ,ja" staje się nieuprzedzonym obserwatorem własnego życia intencjonalnego. Epoché domaga się, zdaniem Husserla, oczyszczenia, przemiany ,ja”, które wyzute z wszelkich światowych uprzedzeń, realizuje zadanie bezstronnej, niezawisłej obserwacji swego świadomościowego życia. Transcendentalna epoché, ujmowana jako zmiana nastawienia, nie jest jedynie metodą warunkującą przejście na poziom transcendentalnej refleksji, lecz przemianą polegającą na przyglądaniu się własnemu ,ja" w nowym świetle, na uświadomieniu sobie przez ,ja”, że stanowi ono siłę konstytuującą. Transcendentalną epoché można $\mathrm{w}$ ramach takiego ujęcia rozumieć jako postępowanie neutralizujące rozdźwięk związany z paradoksem podmiotowości. W Medytacjach kartezjańskich Husserl pisze, że realizacja redukcji fenomenologicznej ujawnia dwa odmienne nastawienia ,ja”: o ile w nastawieniu naturalnym ,ja" przeżywa siebie w perspektywie zaangażowania w świat, o tyle dopiero w nowym, transcendentalnym nastawieniu może dostrzec, że wszelki byt istnieje $\mathrm{z}$,aktualnie posiadanym sensem” wyłącznie ze względu na niego i tylko dla niego ${ }^{28}$. Husserl pokazuje, że „ja”, które żyje w naturalnym świecie, jest zarazem ,ja” transcendentalnym. „Z cała oczywistością można powiedzieć: jako żyjące w naturalnym nastawieniu $\mathrm{Ja}$, jestem równocześnie i za każdym razem (auch und immer) Ja transcendentalnym, dowiaduję się o tym jednak dopiero, przeprowadzając redukcję fenomenologiczną"29.

Według Husserla, ,ja" transcendentalne, konstytuujące sens wszystkich dziedzin bytowych, może zarazem przyglądać się sobie przez pryzmat własnych dokonań. W tym kontekście warto przywołać przeprowadzoną przez Eugena Finka interpretację epoché. Wybitny komentator i współpracownik Husserla ujmuje redukcje jako duchowe poruszenie, przenikające całego człowieka, nie zaś jako czysto intelektualny eksperyment myślowy ${ }^{30}$. W odniesieniu do formułowanej przez Finka interpretacji redukcji Krzysztof Środa zauważa: „Przemiana spowodowana przez redukcję jest nieodwracalna - gdy raz ujrzało się nową perspekty-

\footnotetext{
${ }^{27}$ Tamże, s. 50.

${ }^{28}$ Por. tamże, s. 53-54.

${ }^{29}$ Tamże, s. 53.

${ }^{30}$ E. Fink, Was will die Phänomenologie Edmund Husserls?, [w:] tenże, Studien zur Phänomenologie 1930-1939, Nijhoff, Den Haag 1966, s. 160-161.
} 
wę, nie sposób już o niej całkowicie zapomnieć i powrócić do dawnego życia w naiwności" "31. Akt uświadomienia sobie przez podmiot konstytuujących funkcji własnej świadomości stanowi asumpt do indywidualnej przemiany reflektującego ,ja”. Możliwość przemiany wynika z natury ludzkiej podmiotowości. Okazuje się wyznacznikiem ontycznego statusu ego, ponieważ ,ja” - jak zaznaczyliśmy - może być nie tylko podmiotem konstytuującym świat, ale i przedmiotem - elementem świata przez siebie ukonstytuowanego.

$\mathrm{Na}$ drodze redukcji dokonuje się zatem szczególna przemiana ,ja”, które, będąc zawsze ,ja" transcendentalnym (źródłem wszystkich pozostałych dziedzin bytowych), ma możliwość tematyzacji siebie. W celu potwierdzenia omawianego aspektu epoché warto przytoczyć słowa samego Husserla, że redukcja ,jest powołana do spowodowania całkowitej osobowej przemiany, która byłaby porównywalna najpierw z religijnym nawróceniem, która poza tym kryje w sobie znaczenie największej egzystencjalnej przemiany, jaka jest zadana człowieczeństwu jako takiemu"32. Przyjęcie takiej perspektywy pozwala sformułować tezę, że przemiana ,ja” stanowi wewnętrzną możliwość samej fenomenologii. W Medytacjach kartezjańskich Husserl pisze expressis verbis o absolutnej ascezie poznawczej (Erkenntnisarmut) będącej punktem wyjścia drogi filozoficznego rozwoju ${ }^{33}$. Fundamentalne znaczenie, a zarazem cel samej fenomenologii, ujawnia się wraz z koncepcją epoché, ponieważ - jak zauważa Paul Janssen - naturalne nastawienie ,jest jedynym sposobem życia w świecie, który znała ludzkość aż do transcendentalnej fenomenologii”34. Istotnym argumentem przemawiającym za ujęciem redukcji jako przemiany podmiotu jest fakt, że w swej ostatniej pracy Husserl w sposób szczególny eksponuje etyczne (praktyczne) implikacje redukcji. „Jedna z osobliwych cech redukcji [...] wiąże się z tym - pisze H. Spiegelberg - że nie można wskazać żadnego jasnego powodu, dla którego taka gwałtowna zmiana naszego naturalnego stosunku jest potrzebna. Wszystko, o co dopomina się od początku Husserl, pozostaje kwestią

\footnotetext{
s. 67.

${ }^{31}$ K. Środa, Eugen Fink o fenomenologicznej redukcji, „Przegląd Filozoficzny” 1992, nr 2,

${ }^{32}$ E. Husserl, Die Krisis der europäischen Wissenschaften, dz. cyt., s. 140. „Vielleicht wird es sich sogar zeigen, daß die totale phänomenologische Einstellung und die ihr zugehörige Epochè zunächst wesensmäßig eine völlige personale Wandlung zu erwirken berufen ist, die zu vergleichen wäre zunächst mit einer religiösen Umkehrung, die aber darüber hinaus die Bedeutung der größten existenziellen Wandlung in sich birgt, die der Menschheit als Menschheit aufgegeben ist".

${ }^{33}$ Por. E. Husserl, Medytacje kartezjańskie, dz. cyt., s. 3.

${ }^{34}$ P. Janssen, Geschichte und Lebenswelt, dz. cyt., s. 39.
} 
całkowitej wolności przeprowadzenia takiego aktu intelektualnej ascezy" ${ }^{\prime 35}$. Znaczenie transcendentalnej epoché ma związek z przyjęciem postawy niezaangażowanego badacza, który dokonuje aktu redukcji z własnej woli. Redukcja umożliwiająca refleksję nad dokonaniami ego okazuje się aktem etycznym, ponieważ wymaga zmiany oglądu, przyjęcia nowej postawy. Dokonane w ten sposób zespolenie „ja” ze sferą duchową, znamionujące redukcję transcendentalną, w następujący sposób charakteryzuje P. Graff: „[...] żyjąc w nastawieniu umożliwionym przez tę redukcję, uzyskuje się pewien szczególny rodzaj zespolenia ze światem duchowym, poszerzenie i jednocześnie skoncentrowanie pola świadomości jako oczyszczonego ze wszelkich uwikłań doraźnych. Czysta świadomość sięga do świata idei, tak jak świadomość ejdetyczna sięga do istot, a świadomość naturalna do świata empirycznego. Obraz, jaki się oto przed nami rysuje, jest opisem - albo projektem - drogi, jaką przebyć musi każde Ja, aby uzyskać kolejne szczeble samoświadomości [...]"36. Chodzi o to, by porzucając dotychczas zajmowaną postawę naturalną, spojrzeć nań z innej perspektywy, odmienić nastawienie oraz punkt odniesienia własnego ,ja". Przemiana ta jest związana z rozdźwiękiem, jaki zostaje zdemaskowany $\mathrm{w}$ ramach fenomenologicznej koncepcji podmiotowości, podmiotowości z jednej strony naturalnej, $\mathrm{z}$ drugiej zaś strony transcendentalnej. Istotne znaczenie ma tu przeciwwaga - dwubiegunowość świadomości, wyrażająca się w jej intencjonalnym odniesieniu do przedmiotu, a zarazem w wewnętrznym wglądzie.

Podobnie jak każdy czyn lub wartościowanie dotyczące własnego postępowania $^{37}$, redukcja jest aktem wolności, wolnej woli podmiotu.

\footnotetext{
${ }^{35} \mathrm{H}$. Spiegelberg, The context of the Phenomenological Movement, Martinus Nijhoff, The Hague-Boston-London 1981, s. 64

${ }^{36}$ P. Graff, Fenomenologia jako inicjacja. Próba częściowej rekonstrukcji koncepcji człowieka Edmunda Husserla, „Humanitas” 1980, t. 3, s. 54-55.

${ }^{37}$ Według twórcy fenomenologii każde ,ja” jako bezstronny obserwator, jest zarazem podmiotem rozumnie wartościującym oraz mogącym osądzać swe postępowanie. W rozumieniu Husserla „Postępujemy słusznie, jeśli dowolny niezaangażowany obserwator, przenosząc się $\mathrm{w}$ nasze położenie, musiałby uznać nasze postępowanie. My przenosimy się sami w rolę nieuprzedzonego obserwatora, gdy nasze własne postępowanie osądzamy według poprawności. Niezaangażowany obserwator jest tutaj rozumnie wartościującym podmiotem, który stwierdza, że przekonania fundujące postępowanie są poprawne, że wartościowania dobra (Gutwertungen) są poprawnie dokonane, że to, co wartościujemy jako dobre, faktycznie według jego istoty, a więc generalnie $\mathrm{i}$ według apriorycznych materialnych praw wartości, musiałoby zostać zwartościowane jako dobre, że tak samo w istocie wartości podstawowych dokładnie takie i nie inne preferencje mają swe oparcie w prawach, że według tego to, co najlepsze, jest rzeczywiście najlepszym". E. Husserl, Wyktady z etyki i teorii wartości 1908-1914, thum. L. Ostasz, Wydawnictwo Znak, Kraków 1991, s. 21.
} 
Wolność ,ja", będąca istotną cechą świadomości, leży u podstaw przeprowadzenia redukcji. „Dzięki neutralizującej modyfikacji spojrzenia zauważa J. Derrida - zawsze mogę, w akcie wolności, który sam należy do istoty świadomości, ujmować świat i wszystko, co zależy od jego istnienia, jako fenomen: nie jako rzecz lub świat jawiace się świadomości, ponieważ istnienie rzeczy lub świata już mnie nie interesuje, ale jako jawienie się rzeczy lub świata" 38 . Dzięki wolnemu aktowi redukcji transcendentalnej ujmującemu $\mathrm{w}$ nawias to, co spełniane jest naturalnie, zmiana nastawienia nabiera typowego dla prawdziwej przemiany sensu i radykalizmu. Dopiero takie całościowe przeobrażenie, angażujące jednocześnie wolę i rozum, niesie konsekwencje nie tylko teoriopoznawcze, lecz przede wszystkim etyczne, nie prowadząc przy tym - co należy podkreślić - do dualizmu ontologicznego.

Jeżeli chodzi o etyczny rys epoché, E. Lévinas pisze o transcendentalnej godności, godności transcendentalnej subiektywności, jaką ujawnia redukcja: „Życie subiektywne odsłoni swą transcendentalną godność, kiedy okaże się wcześniejsze od rzeczywistości, która tylko dzięki temu życiu zostaje zidentyfikowana, ale która je pochłania i skazuje na anonimowość" ${ }^{\prime 9}$. Z fenomenologicznego punktu widzenia epoché umożliwia nie tylko przezwyciężenie własnej anonimowości, lecz również wyeksponowanie podmiotowej godności. W tym duchu P. Janssen wyraża przekonanie, że ludzkość zatraca się w świecie, jeżeli nie dokonuje transcendentalnej przemiany za pomocą aktu redukcji ${ }^{40}$. W odniesieniu do tego wymiaru redukcji, skorelowanego z problematyką późnej myśli Husserla, Lévinas uwyraźnia etyczne (praktyczne) znaczenie drogi przez ontologię. Twórca filozofii spotkania pisze wprost, że droga ta, która w jego rozumieniu prowadzi Husserla przez fenomenologię percepcji do redukcji, ,jest lepsza od drogi Kartezjańskiej, obranej w Ideen I oraz w Medytacjach" ${ }^{\prime 1}$. Lévinas, który przechodzi od metafizyki do etyki, zauważa niezwykle trafnie, że: „właśnie odwołując się do Innego, Husserl opisze podmiotowość transcendentalną, która wyrywa Ja z jego izolacji” $^{\prime \prime 2}$. W ramach realizowanej w Kryzysie nauk europejskich drogi przez wspólny świat przeżywany twórca fenomenologii pokazuje pierwotną

38 J. Derrida, Fenomenologia $i$ domknięcie się metafizyki, tłum. M. Kowalska, [w:] Fenomenologia francuska. Rozpoznania. Interpretacje. Rozwinięcia, red. J. Migasiński i I. Lorenc, Wydawnictwo Instytutu Filozofii i Socjologii PAN, Warszawa 2006, s. 150.

39 E. Lévinas, O Bogu, który nawiedza myśl, tłum. M. Kowalska, Wydawnictwo Homini, Kraków 1994, s. 78

${ }^{40}$ P. Janssen, Geschichte und Lebenswelt, dz. cyt., s. 134.

${ }^{41}$ E. Lévinas, O Bogu, który nawiedza myśl, dz. cyt., s. 78.

${ }^{42}$ Tamże, s. 77. 
międzypodmiotową relację. W Medytacjach kartezjańskich z kolei pisze o „współprezentowaniu”, „współobecności”, z jaką mamy do czynienia w odniesieniu do percepcji drugiego , ja" ${ }^{33}$.

Lévinas przyrównuje redukcję do przebudzenia ${ }^{44}$. „Redukcja - jak pisze francuski filozof - będzie przede wszystkim zabiegiem, który pod spoczywaniem w sobie, pozwalającym zaistnieć rzeczywistości odnoszonej do niej samej - odkryje lub przebudzi życie, przykryte stematyzowanym, rozproszonym bytem" ${ }^{45}$. Owo przebudzenie nie tylko wytrąca człowieka z naiwno-naturalnej postawy życiowej, lecz przede wszystkim implikuje radykalną zmianę, przekształcenie oraz przewartościowanie utrwalonego dotychczas naiwno-naturalnego obrazu własnego ,ja”, które partycypuje $\mathrm{w}$ otaczającym świecie ${ }^{46}$. Przewrót ten powoduje poruszenie tego, co pozostawało dotąd zakryte i uśpione. „Przebudzenie pisze Lévinas - to Ja, które zarazem śpi i nie śpi, i dla którego dzieje się to wszystko, co dzieje się w immanencji: [...] bezsenne uderzenia w najbardziej ukrytym zakamarku podmiotowego atomu. To czuwanie jaźni płynące z głębi subiektywności, która transcenduje swą immanencję [...] tę bezsenność Husserl opisuje jednak jako intencjonalność. [...] Przebudzone Ja czuwa nad przedmiotem i nawet w swoim życiu aksjologicznym lub praktycznym pozostaje aktywnością uprzedmiotawiającą. Przebudzenie wiąże się tu $\mathrm{z}$ innością przedmiotu, zakłada zderzenie $\mathrm{z}$ rzeczywistością. To od przedmiotu, od tego, co się odsłania (sich abhebt) $\mathrm{w}$ immanencji, przychodzi pobudzenie, stymulacja" ${ }^{47}$. Redukcja jest w rozumieniu Lévinasa przede wszystkim sposobem przebudzenia ,ja” $\mathrm{z}$ jego własnego zaangażowania $\mathrm{w}$ świat, zabiegiem ujawniającym wymiar pierwotnej dialogiczności. Tak więc, o ile w rozumieniu Husserla punktem wyjścia filozofii pozostaje teza ,ja jestem”, o tyle dla Lévinasa jest nim relacja ,ja” - „ty”. Pomimo zasadniczej różnicy między stanowiskiem Husserla a stanowiskiem dialogicznym w kwestii początku filo-

\footnotetext{
${ }^{43}$ Por. E. Husserl, Medytacje kartezjańskie, dz. cyt., s. 157-161.

${ }^{44}$ E. Lévinas, O Bogu, który nawiedza myśl, dz. cyt., s. 74-75.

${ }^{45}$ Tamże, s. 79.

${ }^{46}$ Etyczny rys relacji „ja” i świata otoczenia eksponuje Francesco Saverio Trincia $\mathrm{w}$ artykule The Ethical Imperative in Edmund Husserl. Autor ten dostrzega, że z jednej strony aktywność podmiotu oraz etyka zachowania ściśle związane są ze zmiennością świata otoczenia. Z drugiej strony, jeśli chodzi o podmiotowość transcendentalną, Husserl odwołuje się do wymiaru wewnętrznej potencjalności, wolności ,ja”, które jako takie, kierując się własnym uznaniem, „może zwracać się w stronę najwyższego dobra” i z tej perspektywy spoglądać na siebie jako konstytuujące źródło. F. S. Trincia, The Ethical Imperative in Edmund Husserl, „Husserl Studies” 2007, vol. 23, s. 170.

${ }^{47}$ E. Lévinas, O Bogu, który nawiedza myśl, dz. cyt., s. 74-75.
} 
zoficznej refleksji, wspólnym elementem tych koncepcji jest rozpoczynanie od tego, co bezpośrednio, naocznie dane.

W związku z etycznym wymiarem epoché i możliwością przezwyciężenia kryzysu, istotna okazuje się również kwestia samoodpowiedzialności. „Operacja świadomości - zauważa P. Ricoeur - która podtrzymuje dzieło refleksji, rozwija właściwe sobie implikacje etyczne przez to, że refleksja jest aktem bezpośredniej odpowiedzialności za siebie"48. Ricoeur rozumie redukcję jako przedsięwzięcie nie tylko epistemologiczne, lecz przede wszystkim etyczne. „Filozoficzna przemiana jest aktem w najwyższym stopniu autonomicznym. To, co nazwaliśmy etycznym niuansem, jest więc bezpośrednio implikowane $\mathrm{w}$ akcie ugruntowującym o tyle, o ile akt ten może być jedynie samoustanawiającym. W tym właśnie sensie jest on w najwyższym stopniu odpowiedzialny za siebie. Samostwierdzający charakter ugruntowania konstytuuje podmiot filozoficzny w podmiot odpowiedzialny" ${ }^{49}$. Filozoficzna przemiana warunkuje rzetelną refleksję. Przemiana ta nie polega na zmianie treściowej zawartości świadomości, lecz na „przejściu od wiary w istnienie do sensu istnienia" ${ }^{50}$ i jako taka jest przemianą filozofującego ,ja”, którego odpowiedzialność dotyczy nie tylko krytycznej i bezstronnej obserwacji życia naturalnego, lecz również samego siebie, zaangażowanego $\mathrm{w}$ ten świat. „Filozof - pisze Husserl - musi w pewien sposób w epoché »naturalnie przeżywać« życie naturalne, a jednak epoché powoduje ogromną przemianę przez to, że zmienia charakter problematyki, a w dalszej kolejności przekształca cel poznania, co się tyczy całego sensu jego istnienia" ${ }^{51}$. Redukcja odsłaniająca możliwość wewnętrznego przeobrażenia człowieczeństwa i jednocześnie indywidualnej przemiany ,ja”, stanowi tym samym wyzwanie rzucone myśleniu w ogóle. Husserl w Kryzysie... podkreśla, że „prawdziwe istnienie jest idealnym celem, zadaniem episteme »rozumu«, przeciwstawionym istnieniu, które jest jedynie mniemane i bez pytania zrozumiałe jako »oczywiste« w doxa" ${ }^{52}$. Filozoficzna refleksja, wychodząca od ego cogito, pozostaje idealnym zadaniem, jakie stawia podmiotowi życie $\mathrm{w}$ świecie.

\footnotetext{
${ }^{48}$ P. Ricoeur, Fenomenologia i hermeneutyka: Wychodzac od Husserla, tłum. M. Drwięga, [w:] Fenomenologia francuska, dz. cyt., s. 199.

${ }^{49}$ Tamże, s. 199-200.

${ }^{50}$ Por. tamże.

${ }^{51}$ E. Husserl, Die Krisis der europäischen Wissenschaften, dz. cyt., s. 180. Cyt. za polskim przekładem fragmentów Kryzysu... - Tenże, Wybór pism, tłum. S. Walczewska, [w:] K. Święcicka, Husserl, Wiedza Powszechna, Warszawa 2005, s. 268.

${ }_{52}$ Tamże, s. 11. Cyt. za polskim przekładem fragmentów Kryzysu... - Tenże, Kryzys nauk europejskich, dz. cyt., s. 15.
} 
Husserlowska koncepcja redukcji transcendentalnej rozumiana jako możliwość odsłaniania konstytutywnych dokonań świadomości zakrytych $\mathrm{w}$ nastawieniu naturalnym, stanowi istotny element projektu fenomenologii transcendentalnej. Akt uświadomienia sobie przez podmiot konstytuujących funkcji własnej świadomości stanowi asumpt do indywidualnej przemiany reflektującego ,ja" będącej przemianą całego człowieczeństwa wynikającą z natury ludzkiej podmiotowości. Już w tytule ostatniego dzieła zostaje podkreślony podstawowy wątek fenomenologii transcendentalnej, który obejmuje swym zakresem sferę praxis i theorein. Przyjęcie takiej perspektywy pozwala sformułować tezę, że przemiana „ja” stanowiąca możliwość fenomenologii, jest drogą prowadzącą do przezwyciężenia kryzysu. W świetle projektu fenomenologii transcendentalnej, zostaje tym samym ukazana możliwość nowego spojrzenia na problem statusu ,ja”, czyli na źródło, z którego bierze początek wszelkie naukowe dociekanie.

\section{Między teorią a praktyką}

W ramach projektu fenomenologii transcendentalnej Husserl zmierza do tego, aby przywrócić teoretycznej refleksji jej odniesienie do życia praktycznego. Postawę naukową powinien, jego zdaniem, cechować krytycyzm, a zarazem zorientowanie na konkret. Husserlowski projekt fenomenologii transcendentalnej, uwzględniający zamysł restytucji kultury oraz człowieczeństwa i dokonujący się z punktu widzenia samego „ja”, stanowi próbę przywrócenia harmonii między dziedziną praktyczną (etyczną) i dziedziną teoretyczną: ukazania paralelności dociekań normatywnych (idealnych) z rozumową refleksją nad wymiarem praxis. Etyczne implikacje Husserlowskiej fenomenologii są wszak wynikiem rozważań nad najwyższymi celami życiowymi oraz regułami, których wskazanie (przypomnienie) powinno ułatwić działającej jednostce trud rozumnego uporządkowania życia ze względu na te cele. Kryzys ludzkości europejskiej okazuje się $\mathrm{w}$ istocie załamaniem „ogólnej sensowności jej życia kulturalnego”, kryzysem dotyczącym „całej jej egzystencji” ${ }^{53}$. Załamanie się wiary w rozum, w sens, jawi się jako symptom kryzysu nauki, kultury i człowieczeństwa. Redukcja - jak już była mowa - powołana jest zdaniem Husserla do spowodowania całkowitej osobowej przemiany „ja”, jego egzystencjalnego przeobrażenia ${ }^{54}$. Tę możliwość

\footnotetext{
${ }^{53}$ Tamże, s. 10. Cyt. za polskim przekładem Kryzysu... - Tenże, Kryzys nauk europejskich, dz. cyt., s. 14.

${ }^{54}$ Tenże, Die Krisis der europäischen Wissenschaften, dz. cyt., s. 140.
} 
duchowej przemiany można więc interpretować jako możliwość wkroczenia na wyższy szczebel rozwoju rozumu. Wraz z narodzinami postawy teoretycznej ludzkość osiąga wyższy szczebel człowieczeństwa. Sam Husserl określa filozofię jako „zdobywanie samowiedzy przez ludzkość" 55 . Fenomenologię jako filozofię (naukę, a zarazem sposób postępowania, postawę) związaną z ideą redukcji, służącą przebudzeniu ego, Husserl rozumie jako drogę właściwą, prowadzącą na najwyższy etap rozwoju rozumu.

Podsumowując dotychczasowe rozważania, należy stwierdzić, że choć na podstawie rozważań, przeprowadzonych przez autora Kryzysu nauk europejskich, nie można aksjologiczno-etycznych implikacji Husserlowskiego projektu fenomenologii określić mianem zwartego oraz systematycznego zbioru twierdzeń, to jednak ich wartość, ze względu na powiązanie $\mathrm{z}$ doświadczeniem, pozostaje niepodważalna. Filozofia zaprojektowana przez Husserla jest wynikiem krytycznego namysłu nad zjawiskami i rodzajami doświadczeń, które pojawiają się „tu i teraz”, w żywej teraźniejszości. Husserl wykazuje, że kryzys człowieczeństwa ma swe źródło w zapoznaniu tego, co podstawowe i w sensie genezy pierwotne. W rezultacie idealizacji, odejścia od konkretu, od życia, nauki matematyczno-przyrodnicze oddaliły się od tego, co podstawowe i najistotniejsze. W odniesieniu do takiej hipotezy Lyotard stwierdza, że ,jedynie transcendentalizm - modelujący wszelką wiedzę wedle fundamentalnego »Ja« jako dawcy sensu, żyjący przedobiektywnym, prescjentyficznym życiem w bezpośrednim »świecie życia codziennego«, którego przebraniem tylko jest nauka ścisła - może dostarczyć obiektywizmowi prawdziwych podstaw i odebrać mu jego alienującą moc; filozofia transcendentalna bowiem czyni możliwym pogodzenie obiektywizmu i subiektywizmu, abstrakcyjnej wiedzy i konkretnego życia. Tym samym los europejskiego człowieczeństwa, który jest zarazem losem całej ludzkości, związany jest z szansami zwrotu w stronę fenomenologii”, ${ }^{156}$.

Filozofowanie jest dla Husserla przede wszystkim aktem etycznym. „„Filozofia jest bohaterstwem“, powiedział Husserl. Tylko z pobudek etycznych lub religijnych można dojść do filozofii [...] bo odpowiedzialność czyni nas ludźmi, odpowiedzialność za to, czym

\footnotetext{
${ }^{55}$ Tenże, Filozofia jako zdobywanie samowiedzy przez ludzkość, tłum. Z. Krasnodębski, „Studia Filozoficzne” 1984, nr 2, s. 174-179.

${ }^{56}$ J.-F. Lyotard, Fenomenologia, dz. cyt., s. 54.
} 
jesteśmy i czym jest świat". ${ }^{57}$ Wzięcie odpowiedzialności za własne wybory i czyny, będące przejawami życia transcendentalnej świadomości, jest autonomicznym aktem wolności Ja. Istotnym walorem rozważań Husserla, jest uwyraźnienie faktu, iż poza istnieniem biologicznym i psychicznym, poza istnieniem subiektywnym, wkraczamy również, jako podmioty sprawcze, w przestrzeń racji, wkraczamy do dziedziny racjonalności, a kiedy to czynimy, to "wykraczamy poza«, transcendujemy subiektywność, działamy jako ego transcendentalne" ${ }^{\text {"58 }}$. Zadanie transcendentalnej fenomenologii okazuje się par excellence terapeutyczne, bowiem polega na pokazaniu, że możliwe jest wyjście z kryzysu i przemiana.

\section{Bibliografia}

Blaustein L., Edmund Husserl i jego fenomenologia, „Przegląd Humanistyczny" 1930, nr 2.

Czarkowski J., Filozofia czystej świadomości, Wydawnictwo UMK, Toruń 1994.

Derrida J., Fenomenologia i domknięcie się metafizyki, tłum. M. Kowalska, [w:] Fenomenologia francuska. Rozpoznania. Interpretacje. Rozwinięcia, red. J. Migasiński i I. Lorenc, Wydawnictwo Instytutu Filozofii i Socjologii PAN, Warszawa 2006.

Fink E., Was will die Phänomenologie Edmund Husserls?, [w:] tenże, Studien zur Phänomenologie 1930-1939, Nijhoff, Den Haag 1966.

Graff P., Fenomenologia jako inicjacja. Próba częściowej rekonstrukcji koncepcji czlowieka Edmunda Husserla, „Humanitas” 1980, t. 3.

Husserl E., Die Krisis der europäischen Wissenschaften und die transzendentale Phänomenologie. Eine Einleitung in die phänomenologische Philosophie, hrsg. von W. Biemel, [w:] Husserliana - Edmund Husserl, Gesammelte Werke, bd. 6, Kluwer Academic Publishers, Den Haag 1962. Cyt. również za polskimi przekładami fragmentów Kryzysu...: Kryzys europejskiego czlowieczeństwa a filozofia, ttum. J. Sidorek, Fundacja Aletheia, Warszawa 1993; Kryzys nauk europejskich i fenomenologia transcendentalna, tłum. S. Walczewska, Wydawnictwo Rolewski, Torun 1999; Wybór pism, tłum. S. Walczewska, [w:] K. Święcicka, Husserl, Wiedza Powszechna, Warszawa 2005.

\footnotetext{
${ }^{57}$ Por. L. Blaustein, Edmund Husserl i jego fenomenologia, „Przegląd Humanistyczny“ 1930, nr 2, s. 241.

${ }^{58}$ R. Sokolowski, Wprowadzenie do fenomenologii, dz. cyt., s. 125.
} 
Husserl E., Erste Philosophie (1923/24), teil 2: Theorie der phänomenologischen Reduktion, hrsg. von R. Boehm, [w:] Husserliana - Edmund Husserl, Gesammelte Werke, bd. 8, M. Nijhoff, Den Haag 1959.

Husserl E., Filozofia jako ścista nauka, tłum. W. Galewicz, Fundacja "Aletheia", Warszawa 1992.

Husserl E., Filozofia jako zdobywanie samowiedzy przez ludzkość, thum. Z. Krasnodębski, „Studia Filozoficzne” 1984, nr 2.

Husserl E., Idee czystej fenomenologii i fenomenologicznej filozofii, ks. 2, thum. D. Gierulanka, PWN, Warszawa 1974.

Husserl E., Medytacje kartezjańskie $z$ dodaniem uwag krytycznych Romana Ingardena, tłum. A. Wajs, PWN, Warszawa 1982.

Husserl E., Vorlesungen über ethik und wertlehre 1908-1914, hrsg. von U. Melle, [w:] Husserliana - Edmund Husserl, Gesammelte Werke, bd. 28, Kluwer Academic Publishers, Dordrecht-Boston-London 1950.

Husserl E., Wyktady z etyki i teorii wartości 1908-1914, thum. L. Ostasz, Wydawnictwo Znak, Kraków 1991.

Janssen P., Geschichte und Lebenswelt. Ein Beitrag zur Diskussion von Husserls Spätwerk, Martinus Nijhoff, Den Haag 1970.

Lévinas E., O Bogu, który nawiedza myśl, tłum. M. Kowalska, Wydawnictwo Homini, Kraków 1994.

Lyotard J.-F., Fenomenologia, tłum. J. Migasiński, Wydawnictwo KR, Warszawa 2002.

Łaciak P., Anonimowość jako granica poznania w fenomenologii Edmunda Husserla, Wydawnictwo Uniwersytetu Śląskiego, Katowice 2012.

Mensch J., Manifestation and the Paradox of Subjectivity, „Husserl Studies” 2005, vol. 21.

Ricoeur P., Fenomenologia i hermeneutyka: Wychodzac od Husserla, thum. M. Drwięga, [w:] Fenomenologia francuska. Rozpoznania. Interpretacje. Rozwinięcia, red. J. Migasiński i I. Lorenc, Wydawnictwo Instytutu Filozofii i Socjologii PAN, Warszawa 2006.

Sokolowski R., Wprowadzenie do fenomenologii, thum. M. Rogalski, Wydawnictwo WAM, Kraków 2012.

Spiegelberg H., The context of the Phenomenological Movement, Martinus Nijhoff, The Hague-Boston-London 1981.

Środa K., Eugen Fink o fenomenologicznej redukcji, „Przegląd Filozoficzny” 1992, $\mathrm{nr} 2$.

Trincia F. S., The Ethical Imperative in Edmund Husserl, „Husserl Studies” 2007, vol. 23.

Zahavi D., Fenomenologia Husserla, tłum. M. Święch, Wydawnictwo WAM, Kraków 2012. 


\section{Summary}

\section{Husserl's Understanding of Crisis and the Transcendental Phenomenology}

Phenomenology as a science on transcendental subjectivity has been established through the critical consideration of the idea of cognition. The interpretation of crisis presented in the article is a result of analyses concerning the theoretical and practicalethical motives in Husserl's philosophy. From this point of view, phenomenology can be understood as a science striving to consolidate cognition and reveal findings that are relevant to one's life. In the article we will show that the idea of phenomenology evolves in connection with considerations outlining a horizon of classic philosophical problems: epistemologic, metaphysical and ethical.

Keywords: phenomenology, crisis of science, transcendental reduction, cognition

\section{Zusammenfassung}

\section{Husserls Auffassung der Krise und die transzendentale Philosophie}

Die Phänomenologie als Lehre über die transzendentale Subjektivität wurde im Zusammenhang mit der kritischen Reflexion über die Idee der Erkenntnis begründet. In diesem Artikel werden die Überlegungen zum Sujet der Krise als Endeffekt der Untersuchungen dargestellt, die dem theoretischen und praktisch-ethischen Motiv des Gedankens von Husserl gelten. Von diesem Standpunkt aus kann die Phänomenologie als eineWissenschaft verstanden werden, die die Einheit der Erkenntnis ermöglicht und lebenswichtige Befunde offenbart. Im Artikel wird gezeigt, dass die Idee der Phänomenologie im Zusammenhang mit den Betrachtungen evoluiert, die den Horizont der klassischen philosophischen Probleme umfassen: der epistemologischen, metaphysischen und ethischen.

Schlüsselworte: Phänomenologie, die Krise der Wissenschaften, transzendentale Reduktion, Erkenntnis

Information about Author:

AGNIESZKA WESOŁOWSKA, PhD, Institute of Philosophy, Uniwersity of Silesia, Cathedral of Philosophical Anthropology, Poland; adress for correspondence: ul. Bankowa 11, PL 40-007 Katowice. E-mail: aletheia2@interia.pl 